\title{
EXPERIMENTAL STUDIES ON LATERITE SOIL STABILIZED WITH CEMENT AND AGGREGATE
}

\author{
SunkaraYashwant ${ }^{1}$, B. Someswara Rao ${ }^{2}$, G. Venkata Rao ${ }^{3}$ \\ ${ }^{I}$ P.G student, Department of Civil Engineering, GMR Institute of Technology, Andhra Pradesh, India \\ ${ }^{2}$ Asst. Professor, Department of Civil Engineering, GMR Institute of Technology, Andhra Pradesh, India \\ ${ }^{3}$ Professor, Department of Civil Engineering, GMR Institute of Technology, Andhra Pradesh, India
}

\begin{abstract}
The subgrade must be able to support loads transmitted from pavement structure without excessive deformation under adverse climatic and traffic conditions to increase the life of the pavement. It is a well known fact that, all soils do not possess all the desirable qualities for using it as good quality pavement material. When such soils cannot be replaced, its subgrade performance should be increased by several modification techniques. The place where ground water table is high, the strength of subgrade is adversely affected by moisture infiltration to subgrade and base due to capillary action. The purpose of this paper is to evaluate the use of low contents of cement and aggregate in the modification of a lateritic soil properties concerning the behavior of mixtures to use in the base construction. In the present study an effort is made to obtain the optimum dosage of cement for stabilization of locally available lateritic soil. The study incorporates investigations on basic properties of soil. Then the investigations are carried out to study the effect of addition of $10 \mathrm{~mm}$ down aggregates to the soil properties added in addition to the obtained optimum cement content to evaluate the extent of modification on MDD, OMC and CBR of the soil. The experimental investigations shown that there is a tremendous increase in the CBR value of the soil treated with cement-aggregate modification. After conducting all the tests see whether it's strength is suitable for base coarse. In addition, the field cost analysis is also made to compare the cost of construction for various modifications used.
\end{abstract}

Keywords: lateritic soil 1, Cement 2, Aggregates3, Stabilization4 and CBR5

\section{INTRODUCTION}

Shortage of crushed rock as pavement base course for road construction and an increase in fuel cost have prompted the search for alternative materials. In this regard, improvements of the lateritic soil cement (LSC) have been investigated. [1] Saravut Jaritngam, An investigation of lateritic Soil Cement for Sustainable Pavements. Lateritic soils are soil types rich in iron and aluminum, distributed in many areas of the world. The purpose of this paper to improvement of lateritic soil with cement and aggregate mixing was modified for base course materials to improve performance. . Lateritic soil was mixed with cement for economical and environmental propose, the cement content in the additive should be as low as possible. Cement treatment has become an accepted method for increasing the strength and durability of soils. Marginal aggregates are also used to reducing quantity of cement. The scope of this study is limited to the laboratory tests using laterite soil. Basic tests such as Atterberg limits test, grain size analysis test, compaction test, California Bearing Ratio test, Triaxial test and Unconfined Compressive Strength test are done to find out the properties of the laterite soil used. Compaction test, CBR test are done to find out the properties of the soil stabilized with cement using dosages of 1,2, 3 and $6 \%$ of weight of soil. Also compaction test and CBR test are used to determine properties of soil stabilized with optimum cement and aggregates $(10,20$, and 25\%). From these results the optimum percentage of cement is selected to prepare the treated soil - aggregate mix with $10 \mathrm{~mm}$ down aggregates. Cost analysis was done for cement treated soil and soil, cement, aggregate mixes also carried out to say whether it is economical or not.

\section{MATERIALS AND METHODS}

laterite soil collected from Orissa region at $1.0 \mathrm{~m}$ depth is used for the study. The lateritic soil was sealed in the air tight plastic bags and transported to the college laboratory for testing. After collecting the soil is dried for 2 weeks. The index properties of the soils including Atterberg limits test, grain size analysis test, compaction test, California Bearing Ratio test, Triaxial test and Unconfined Compressive. Strength test were determined in accordance with IS: 2720 test procedures. The soil sample was later stabilized with $1 \%, 2 \%, 3 \%$, and $6 \%$ portland cement by weight of soil. The MDD, OMC, and CBR of the soil were determined at each increase in cement content to ascertain the effect of the addition of varying quantities of cement. After finding the optimum percentage of cement $10 \mathrm{~mm}$ downsize aggregates of 10,20 , and $25 \%$ of weight of soil is added and ascertain its MDD, OMC, and CBR of the cement, aggregate mix treated soil.

\section{RESULTS AND DISCUSSION}

The Index Properties of laterite soil are presented in table1.From Atterberg's limit test are as follows: $\mathrm{LL}=50 \%$ and $\mathrm{PI}=15.8 \%$. According to sieve analysis test the soil can be classified as well graded sand (sw) Grain size distribution curve of laterite soil is shown in fig 1. 


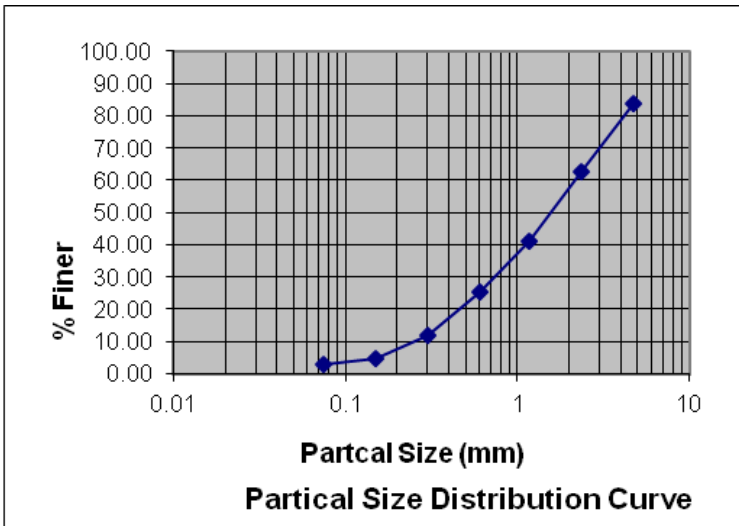

Fig-1: grain size distribution curve of laterite soil

Table 1 Index Properties of laterite soil

\begin{tabular}{|l|l|}
\hline Tests & Results \\
\hline 1. Grain Size Distribution (\%) & \\
a. Gravel & 17.2 \\
b. Sand & 80.4 \\
c. Silt & 2.9 \\
d. Soil Classification & SW \\
\hline 2. Atterberg Limits (\%) & \\
a. Liquid Limit & 41.56 \\
b. Plastic Limit & 24.8 \\
c. Plasticity Index & 16.76 \\
\hline 3. Standard Proctor Test & \\
a. Maximum dry density(g/cc) & 1.82 \\
b. Optimum moisture content & 14 \\
(\%) & \\
\hline 4.Unconfined Compressive & 72 \\
Strength (kPa) & \\
\hline 5. Cohesion (c) & 0.31 \\
\hline 6. Angle of internal friction (\$) & 36.8 \\
\hline 7. California Bearing Ratio (\%) & \\
a. Soaked & 4 \\
b. Un soaked & 5.04 \\
\hline
\end{tabular}

\subsection{Standard Proctor Test}

By compaction of soil, the particles are mechanically constrained to pack more closely, by expelling part of the air voids. Proper compaction of fills, subgrade, sub-base and base courses are considered essential for proper highway construction. There is optimum moisture content for a soil, at which maximum dry density is attained for a particular type and amount of compaction. To assess the amount of compaction and water content required in the field, compaction tests are conducted. In the present study Standard Proctor Compaction test as per IS: 2720 (Part VII), 1980 was conducted on soil without cement. The test is conducted on soil alone, soil with cement dosages (1, 2, 3, and $6 \%$ ) and soil with optimum amount of cement (3\%) and soil with aggregates $(10,20$ and $25 \%)$. The compaction test is done immediately after treating it with the stabilizer. The test results of compaction test with soil alone, soil with cement dosages $(1,2,3$, and $6 \%)$ and soil with optimum amount of cement (3\%) and soil with aggregates (10,20 and $25 \%$ ) were shown in Table 2 and 3 . likewise the graphs were shown in fig 2, 3, and 4

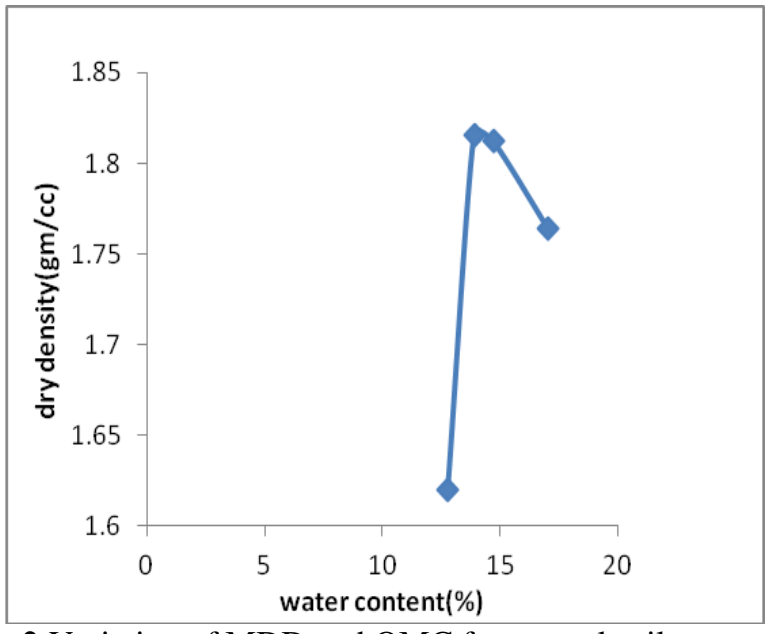

Fig-2:Variation of MDD and OMC for natural soil

Table 2 MDD and OMC of Various Cement

\begin{tabular}{|ll|l|l|}
\hline Sample & OMC (\%) & MDD(gm/cc) \\
\hline Natural soil & 14 & 1.82 \\
\hline $\begin{array}{l}\text { Soil+ } \\
\text { Cement }\end{array}$ & 8.45 & 1.921 \\
\hline $\begin{array}{l}\text { Soil+ } \\
\text { Cement }\end{array}$ & 10 & 1.93 \\
\hline $\begin{array}{l}\text { Soil+ } \\
\text { Cement }\end{array} \quad 3 \%$ & 9.7 & 1.94 \\
\hline $\begin{array}{l}\text { Soil+ } \\
\text { Cement }\end{array}$ & 11.6 & 1.88 \\
\hline
\end{tabular}

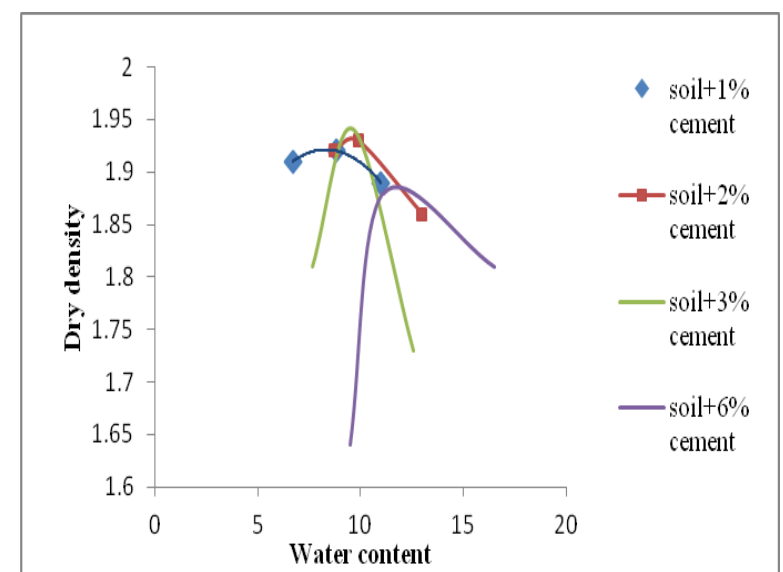

Fig-3: Variation of MDD and OMC for Various Cement

Dosages

Table 3 Variation of MDD and OMC for optimum percentage of cement with Various aggregate percentages

\begin{tabular}{|l|l|l|}
\hline Sample & $\begin{array}{l}\text { OMC } \\
(\%)\end{array}$ & MDD(gm/cc) \\
\hline $\begin{array}{l}\text { Natural soil +3\%cement+ } \\
\text { 10\%aggregates }\end{array}$ & 9 & 1.93 \\
\hline $\begin{array}{l}\text { Natural soil +3\%cement+ } \\
\text { 20\%aggregates }\end{array}$ & 8.7 & 1.97 \\
\hline $\begin{array}{l}\text { Natural soil +3\%cement+ } \\
\text { 25\%aggregates }\end{array}$ & 9.1 & 2.02 \\
\hline
\end{tabular}




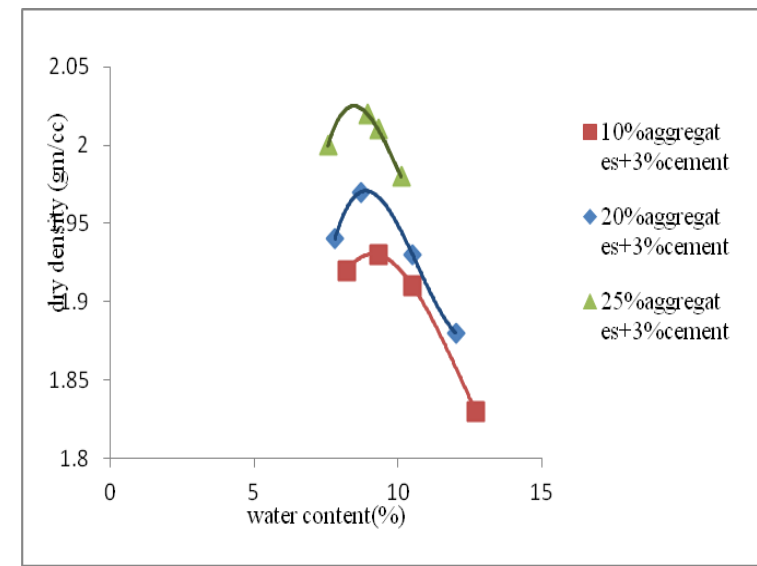

Fig- 4: Variation of MDD and OMC for Various aggregate percentages

\subsection{California Bearing Ratio (CBR)}

CBR value for untreated soil remained constant for most of the time. When soil treated with cement as the cement dosage was increased CBR values also increased for all curing periods. It can be explained like curing aids development of strength of cement because it reduces heat of hydration and development of tricalcium silicates and dicalcium silicates takes place and are responsible for strength of cement. In untreated soil there is no cementitious material so therefore there wasn't any development of strength. The test results of CBR test with soil alone, soil with cement dosages $(1,2,3$, and $6 \%)$ were shown in Table 4 and 5 likewise the graphs were shown in fig 5,6,7 and 8

Table 4 Soaked CBR Values for Various Cement dosages

\begin{tabular}{|l|l|l|l|l|}
\hline \multicolumn{4}{|l|}{ Soaked CBR Values (\%) } \\
\hline $\begin{array}{l}\text { Curing Period } \\
\text { (days) }\end{array}$ & 0 & 7 & 14 & 28 \\
\hline Soil + 1\% cement & 15 & 20 & 25 & 31 \\
\hline Soil + 2\% cement & 17 & 31 & 36 & 40 \\
\hline Soil + 3\% cement & 20 & 39 & 45 & 52 \\
\hline Soil + 6\% cement & 25 & 60 & 72 & 76 \\
\hline
\end{tabular}

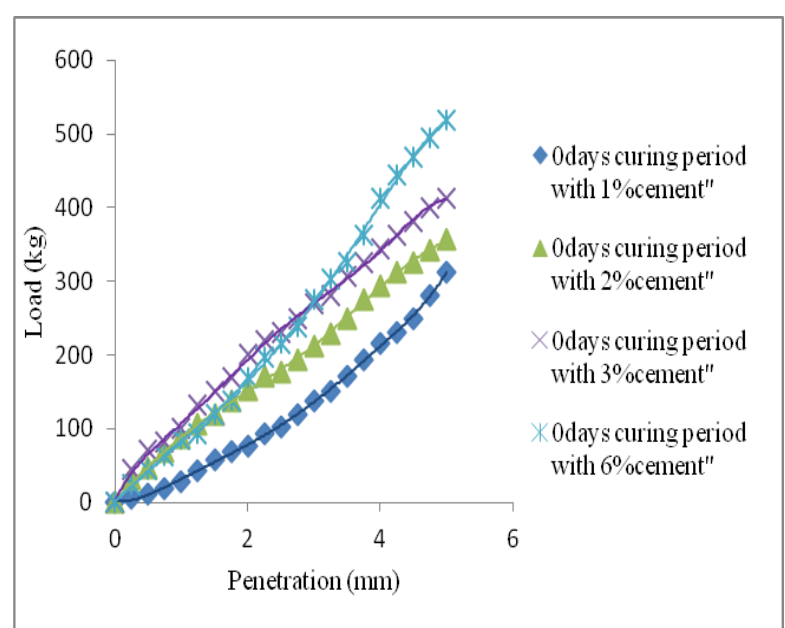

Fig- 5: Soaked CBR graphs for 0 days curing period with various Cement dosages.

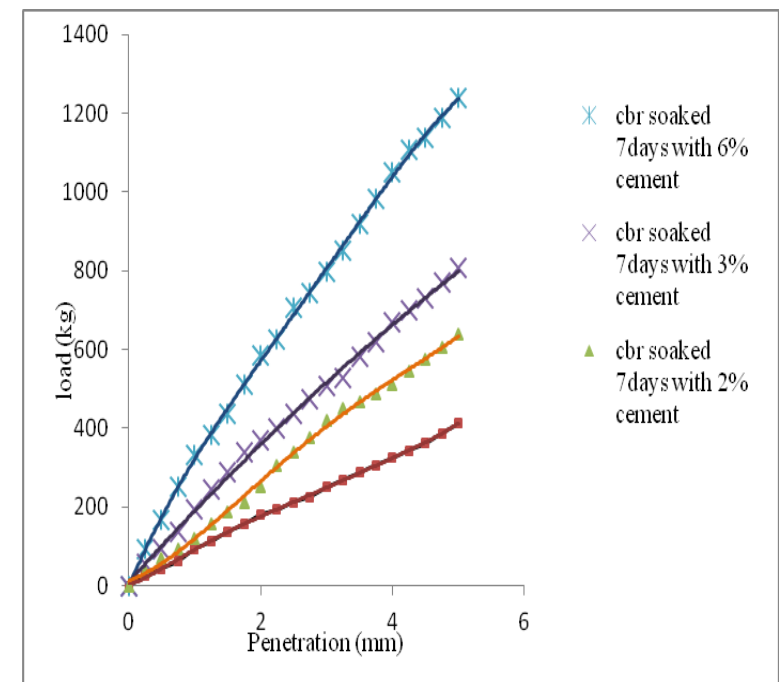

Fig- 6: Soaked CBR graphs for 7 days curing period with various Cement dosages

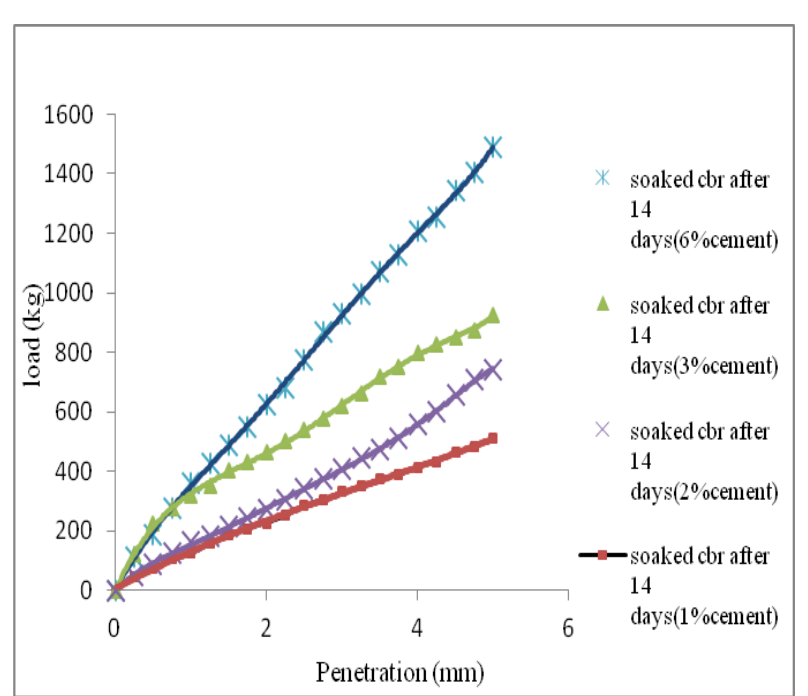

Fig- 7: Soaked CBR graphs for 14 days curing period with various Cement dosages

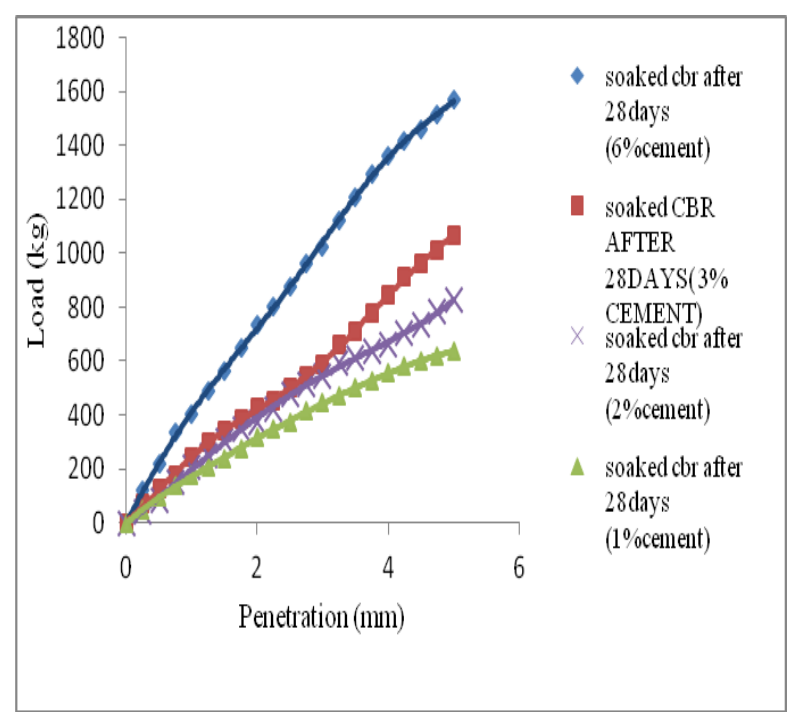

Fig- 8: Soaked CBR graphs for 28 days curing period with various Cement dosages 
After finding optimum percentage of cement addition of $10 \mathrm{~mm}$ downsize aggregates of 10,20 , and $25 \%$ of weight of soil compaction and CBR tests were conducted. CBR value for soil treated with optimum percentage of cement as the aggregate percentage increases CBR values also increases for all curing periods. The soaked CBR values of Various aggregate percentages with optimum percentage of cement were mentioned in table 5 and it's graphs were indicated in fig $9,10,11$ and 12

Table 5 Soaked CBR Values for Various aggregate percentages with optimum percentage of cement

\begin{tabular}{|l|l|l|l|l|}
\hline \multicolumn{2}{|l|}{ Soaked CBR Values (\%) } \\
\hline Curing Period (days) & 0 & 7 & 14 & 28 \\
\hline $\begin{array}{l}\text { NaturalSoil+3\%Cement+ } \\
10 \% \text { aggregates }\end{array}$ & 33.4 & 61 & 72 & 80 \\
\hline $\begin{array}{l}\text { NaturalSoil+3\%Cement+ } \\
\text { 20\%aggregates }\end{array}$ & 35.8 & 70 & 85 & 92 \\
\hline $\begin{array}{l}\text { NaturalSoil+3\%Cement+ } \\
\text { 25\%aggregates }\end{array}$ & 38.3 & 77 & 92 & 98 \\
\hline
\end{tabular}

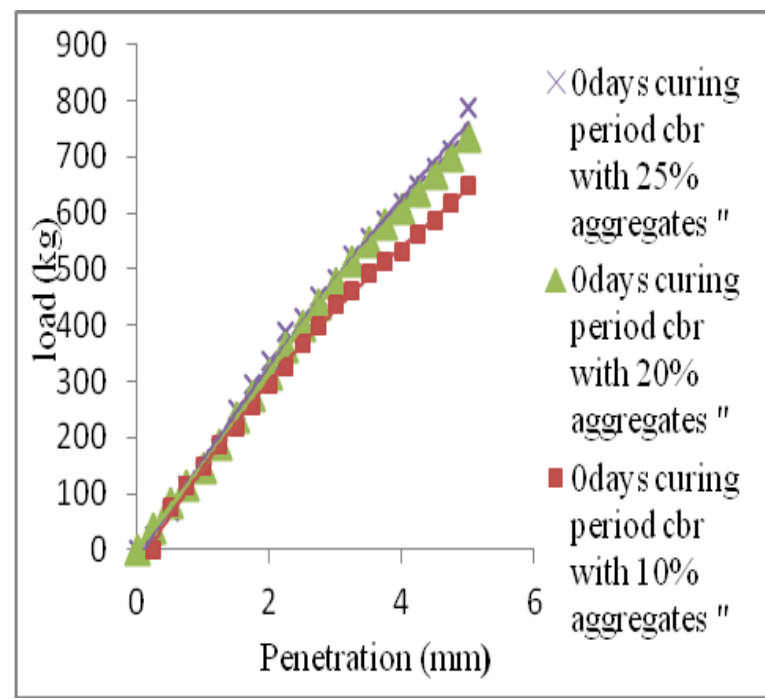

Fig- 9: Soaked CBR graphs for for 0 days curing period with Various aggregate percentages and optimum percentage of cement

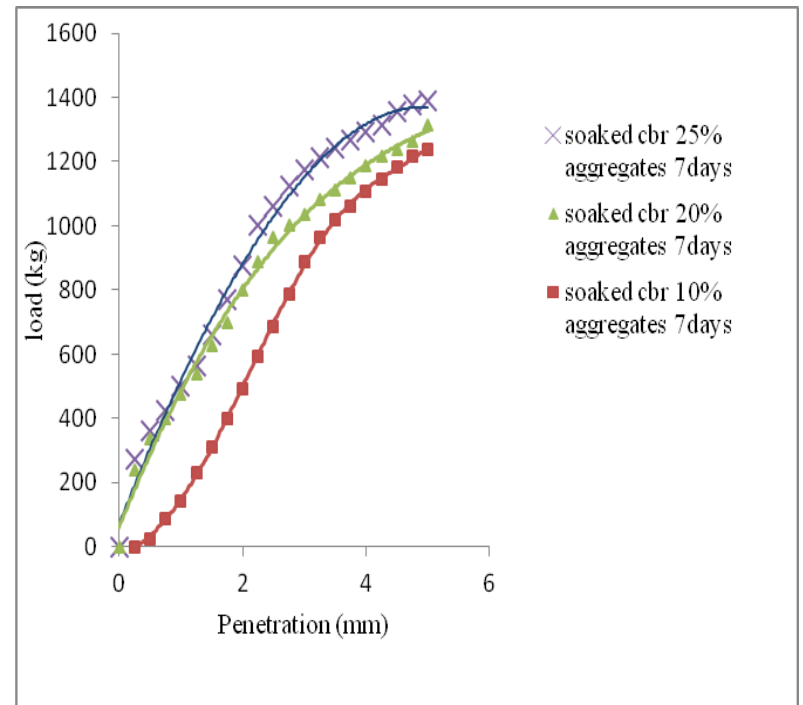

Fig- 10: Soaked CBR graphs for for 7 days curing period with Various aggregate percentages and optimum percentage of cement



Fig- 11: Soaked CBR graphs for for 14 days curing period with Various aggregate percentages and optimum percentage of cement

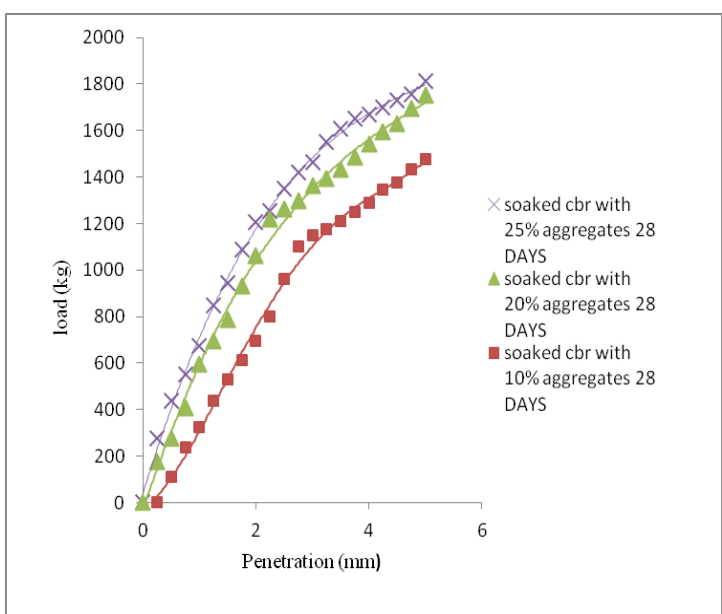

Fig- 12:. Soaked CBR graphs for for 28 days curing period with Various aggregate percentages and optimum percentage of cement 


\section{COST ANALYSIS}

In a developing country like India, the materials used for construction should be cost effective. Hence a cost comparison is required for recommending any new material. Through this study it was found that cement increases the CBR value of lateritic soil and optimum dosage of cement was found. Before recommending cement for practical purpose for stabilizing weak subgrade soils, a cost comparison was to be done to ascertain whether it proves cost effective on the longer run. Any new material or method will be accepted only if it is cost effective. It is observed that, with the optimum cement content as the percentage of aggregates increases, the cost of soil per unit volume increases. Hence, soil treated with $10 \%$ of aggregates in addition to optimum cement content is preferred.

Table 6 Cost of different combination of treated soil Cost Analysis of the Treated Lateritic Soil

\begin{tabular}{|l|l|l|}
\hline $\begin{array}{l}\text { CBR values and Cost of different combination } \\
\text { of treated soil Cost Analysis of the Treated } \\
\text { Lateritic Soil }\end{array}$ \\
\hline Property & CBR (\%) & $\begin{array}{l}\text { Cost the soil } \\
\text { per m3 }\end{array}$ \\
\hline Natural Soil & 4 & Rs.600 \\
\hline $\begin{array}{l}\text { Soil+3\% } \\
\text { Cement }\end{array}$ & 52 & Rs.706 \\
\hline $\begin{array}{l}\text { Soil+3\% } \\
\text { Cement+10\% } \\
\text { Aggregates }\end{array}$ & 80 & Rs.976 \\
\hline $\begin{array}{l}\text { Soil+3\% } \\
\text { Cement+20\% } \\
\text { Aggregates }\end{array}$ & 92 & Rs. 1081 \\
\hline $\begin{array}{l}\text { Soil+3\% } \\
\text { Cement+25\% } \\
\text { Aggregates }\end{array}$ & 98 & Rs. 1093 \\
\hline
\end{tabular}

\section{CONCLUSION}

Stabilization is the process of mixing ordinary Portland cement and aggregate with a lateritic soil to produce strength which is greater than that of the original soil. The soaked CBR at 3 percentages of cement increased up to $48 \%$ at 28days curing period when compared to that of untreated soil. Likewise unsoaked CBR increased up to $15 \%$. When soaked CBR is conducted with optimum percentage of cement (3\%) with $10 \%$ aggregate, it's strength increased up to $76 \%$. Likewise unsoaked CBR increased up to $28.36 \%$. In conclusion, stabilized lateritic soil can be used as road base course. Only about $3 \%$ by weight of the Portland cement and $10 \%$ aggregate is enough to stabilize lateritic soil to meet the Department of Highways specification. Furthermore, the use of stabilized lateritic soil decreases environmental problems in decreasing demand on crushed rock.

\section{REFERENCES}

[1] G. Eason, B. Noble, and I.N. Sneddon, "On certain integrals of Saravut Jaritngam1, Opas Somchainuek And Pichai Taneerananon, An Investigation Of Lateritic Soil Cement For Sustainable Pavements Vol:5 Issue:11 November 2012

[2] F.H.M. Portelinha, D.C. Lima, M.P.F. Fontes, C.A.B. Carvalho, Modification Of A Lateritic Soil With Lime And Cement: An Economical Alternative for Flexible Pavement Layers, March 7, 2012

[3] Onyelowe Ken C and Okafor F. O, A Comparative Review Of Soil Modification Methods, VOL. 1, NO. 2, NOVEMBER 2012

[4] Swapan Kumar Bagui, "Pavement Design for Rural Low Volume Roads Using Cement and Lime Treatment Base", Volume 6, No. 3, 2012

[5] Adrian. O. Eberemu, Consolidation Properties of Compacted Lateritic Soil Treated with Rice Husk Ash September 20, 2011

[6] Jose N.Gomez S. David M. Anderson, Soil Cement Stabilization - Mix Design, Control and Results during Construction, 1 June 2012

[7] Olugbenga Oludolapo Amu, Oluwole Fakunle Bamisaye and Iyiola Akanmu Komolafe, The Suitability and Lime Stabilization Requirement of Some Lateritic Soil Samples as Pavement, 18-012011

[8] A. J. Olarewaju, M. O. Balogun and S. O. Akinlolu, Suitability of Eggshell Stabilized Lateritic Soil as Subgrade Material for Road Construction Vol. 16, 2011

[9] Douglas O. A. Osula, Evaluation Of Admixture Stabilization For Problem Laterite, 1989

[10] Manasseh Joel and Isaac O. Agbede, MechanicalCement Stabilization of Laterite for Use as Flexible Pavement Material, 2011

[11] Ahmad Safuan A Rashid "Effect of Stabilized Laterite on California Bearing Ratio (CBR) and Unconfined Compressive Strength (UCS)" Electronic Journal of Geotechnical Engineering, 2013

[12] M. K. Rahman, S. Rehman \& O. S. B. Al-Amoudi, Literature Review on Cement Kiln Dust Usage in Soil And Waste Stabilization And Experimental Investigation International Journal of Research and Reviews in Applied Sciences, 2011

[13] O.F Bamisaye, I.A Komolafe, "The Suitability and Lime Stabilization Requirement of Some Lateritic Soil Samples as Pavemen" International Journal of Pure and Applied Sciences and Technology, 2011

[14] F.C. Ugbe, "Basic Engineering Geological Properties of Lateritic Soils from Western Niger Delta" Research Journal of Environmental and Earth Sciences, 2011

[15] A. E. Oghenero, A. T. Okey, "Classification and compaction characteristics of lateritic soils of Warri" Pelagia Research Library, 2014

[16] Behzad Kalantari, Arun Prasad, "Strength Evaluations for Treated peat with Cement and Polypropylene Fibres using CBR Tests” March, 2013 
[17] S.Horpibulsuka,Apichat PokinChamketa
grainedsoils, lateriticsoils

Suddeepongb, Compactionbehavioroffine1September2012

[18] A.A. Bello, Influence of Compaction Delay on CBR and UCS of Cement Stabilized Lateritic Soil. Volume 12. Number 2.

[19] Adrian. O. Eberemu, Consolidation Properties of Compacted Lateritic Soil Treated with Rice Husk Ash September 20, 2011

[20] Sathawara Jigar K, Comparison Between Soaked And Unsoaked Cbr, Vol. II/ Issue III/April-June, 2013 